Vol. 16 No. 1 - April 2016

\title{
Dignifying Children through Inclusive Children's Literature
}

\author{
Fransisca Kristanti \\ English Letters Department, Sanata Dharma University, Yogyakarta \\ kristanti.fransisca@gmail.com
}

\begin{abstract}
Children with disabilities are often considered less capable than those without disabilities. In Indonesian children's literature, disability is under-represented and the need to start representing disability in Indonesian children's literature is pressing. Inclusive books imposing on the development of empathy leads to actions in dignifying children of all types, with or without disabilities. Some inclusive children's literature worldwide set good examples of dignifying children. This paper tries to elaborate the urgency of having accessible inclusive children's literature in Indonesia by collecting and presenting examples of inclusive children's literature around the world which represents disabilities as diversities in society.
\end{abstract}

Keywords: inclusive children's literature, disability, empathy, dignity

\section{Introduction}

Even though more inclusive schools are emerging throughout Indonesia, the opportunity to interact with people with disabilities in common social interaction is not available to everyone. Some people have limited or even zero access to the interaction with people with disabilities. Therefore, when they find themselves in a situation which requires interaction with people with disabilities, most people find difficulties in behaving appropriately, and sometimes tends to be discriminatory.

Creating accessible materials for people to understand more about disabilities is a way to minimize this. The earlier stage of life people is exposed to these materials, the more possibilities people will understand that disability is a part of reality, thus making it ordinary. Children's literature is a way of engaging children with the notions and representations of difference and diversity. However, the lack of qualified children's literature incorporating characters who experience disabilities is evident in
Indonesia. Therefore, this paper tries to present the urgency of having accessible inclusive children's literature in Indonesia in the attempt to promote empathy which leads to the treatment of dignity towards others.

\section{Inclusion and Dignity}

Disability is under represented in Indonesian children's literature and the need to start representing disability in Indonesian children's literature is pressing. Utilizing technology, the result of the search engine when using the keywords buku (book), cerita (story), literatur (literature), anak (children), inklusi (inclusive), spesial (special), and istimewa (special) shows that there is no - or at least no Internet result of - Indonesian children's literature narrating about people with disabilities. The result shows one limitedly published book titled Kita bisa bersahabat, Rin! (Krismariana and Thomdean, 2007) brings the issue of multiculturalism and religion between children of different backgrounds, Islam and Christians, Javanese and Chinese. This finding illustrates that Indonesian society concerns on the 
discussion of tolerance in the discourse of multiculturalism and religion. Other findings show titles like Model Implementasi Pendidikan Inklusif Ramah Anak (Kustawan and Hermawan, 2013), Buku Ajar Penanganan Anak Usia Dini Berkebutuhan Khusus (Wiyani, 2014), Mari Memahami dan Melindungi Anak melalui Inklusi Sosial (Yuditia, Liandarwati, and Palupi, 2015), Seri Explorasi dan Bermain untuk: Anak Berkebutuhan Khusus (Pramudyawati and ArRizqi, 2014), and some other books with similar topics. These findings illustrate that the responsibility of formulating approaches to children with special needs lies in the hands of adults.

The condition is alarming due to the fact that people with disabilities are a part of the society. Disability leads to many negative consequences such as discrimination in the area of economy, education, profession, participation, and facility. People with disabilities are often regarded as second-class members of the society who are unable to function "normally". This often leads to the idea of putting extra efforts when interacting with people with disabilities which later creates different experiences for both parties, the disabled and the "normal". The environment in which the person live brings a serious impact on the experience and the degree of disability. World Health Organization's report (2011) claims that the environments which are inaccessible for people with disabilities are responsible in creating disabled experiences. These inaccessible environments create barriers to participation and inclusion. Examples of the inaccessible environments include "a Deaf individual without a sign language interpreter, a wheelchair user in a building without an accessible bathroom or elevator, a blind person using a computer without screen-reading software," (WHO 2011: 4).

The lack of supporting environment is the result of the society inability to empathize with people with disabilities. McDonald and Messinger (2011) states that the ability to empathize has a serious effect on relationship quality by being the facilitator of maintaining meaningful relationships. Even though Freud (1958) and Piaget (1965) suggest that young children are cognitively unable to experience empathy due to their egocentricity, more recent studies suggest otherwise. ZahnWaxler et al. (1992) claims that very young children are capable of displaying some variety of rather sophisticated behavior related to empathy and are capable of displaying cognitive empathy when reaching early childhood (Wellman et al., 2001). Therefore, it is important to develop empathy in early childhood to have empathetic adults who will take actions in increasing supporting environment, specifically for people with disabilities.

Empathizing with people with disabilities is a first step to maintain dignity. It is important to extent the right to be treated with dignity to children. Miller in Govindarajan (2015) presents the benefit of treating children with dignity as follow.

"People whose integrity has not been damaged in childhood, who were protected, respected, and treated with honesty will be - both in their youth and adulthood - intelligent, responsive, empathic, and highly sensitive. They will take pleasure in life and will not feel any need to kill or even hurt others or themselves.... They will not be able to do otherwise than respect and protect those weaker than themselves including their children, ...," (6).

Thus, dignity is closely related to the practice of empathy. Exposing children with empathy towards others with disabilities can be done in various way, from formal exposure in educational fields to informal exposure by means of stories. A study by Strayer and Roberts (1997) shows that stories have great influence in developing empathy. When children are exposed to stories, they placed characters from the story physically closer to themselves. This finding suggests empathy may motivate a desire for increased interpersonal closeness which later leads to the treatment of dignity.

\section{Inclusive Children's Literature}

Children's literature, literature written for children, is written for many different 
purposes. Some of the purposes are to entertain and to assist children in comprehending the world they live in. It is also written to introduce new things, including cultures, people, ideas, events, or characters which are relatable to the young people in the process to better understand themselves. Some children's books illustrate characters from different backgrounds to promote tolerance and some others portray characters with disabilities for helping readers to learn, understand, and relate to people with disabilities, and for helping those with disabilities to have a habit of reading for pleasure about characters like themselves, thus comes the term "inclusion".

The definition of inclusion is more widely used in the area of education than in the area of literature. First introduced by Vygotsky in his theories on methodology in special education and psychology, the methodological framework is elaborated in practical implementation of inclusive education for those with dysontogenesis, a deficient development (in comparison to normal individual development). According to this theory, practicing positive-oriented approaches meaning applying a favorable societal perspective on children with disabilities. Strengthening and empowering the individual skills of children with disabilities are preferred over stressing on their weaknesses. Vygotsky considered disability as a "social aberration" (1993: 66), while acknowledging biological condition at the same time. He considers social aberration develops from children's changing social and environmental relations which leads to disturbances in their social behavior. The disability itself is distinguished between primary disability, which is referred as physical impairment, and secondary and tertiary disability, which concerns more on cultural distortions of social condition of mental functions. It is crucial for children with primary, secondary, and tertiary disability to socially interact with other children. The main responsibility of the adults is to lead the child into the general culture and to include them in the socialization with other children. Therefore, inclusive education requires the full inclusion of all children without segregation (Lindsay, 2003).

In the area of literature, the term inclusion is not specifically elaborated in theories. However, taking Vygotsky and Lindsay's definition of inclusion in education, inclusion in literature can be formulated as making the work of literature accessible to people with additional needs and/or including disability or disabled characters within the story. In a booklet for Disability Equality in English Primary Schools (DEEPS) project, Beckett and Barrett's (2008) discussion area of inclusion literature covers specifically on children with disabilities. The project was aimed to help teachers to assess the inclusiveness of children's books for their classroom use. The formulation of the term "inclusion literature" derives from the formulation of inclusion in education. Having inclusion literature is a way to "improve nondisabled children's understanding of disability" and "help them to develop positive attitudes towards disabled people," (Beckett and Barret, 2008: 1).

In modern children's literature, the representations of disabilities are often associated with bravery. Ayala (1999: 112) found that $63 \%$ of the inclusive children's books portray characters with disabilities as "brave little soul", while $10 \%$ portray them as "victims" or "outcasts" and $20 \%$ portray them as "fully functioning members of society". Furthermore, Prater (2003: 47) writes that

"Today, authors include characters with disabilities to (a) focus on the life of an individual with a disability, or (b) tell a story that happens to include an individual with disability. In the first case, fictionalised or true characters may serve as a role models and/or as bibliotherapy .... In the latter case, the authors' intent is not necessarily to provide role models or teach about disabilities, but to represent the diversity in society."

Inclusive children's literature can be understood as literature written for children which illustrates disabilities as inevitable part of society. The idea is to set the new standard of "normality" by presenting diversity as a common situation in our 
society. Children identify with characters who are like themselves. Therefore, stories should present them with a wide range of powerful and competent characters from different backgrounds who represent real people.

\section{Inclusive Children's Literature around the World}

Inclusive children's literature is not uncommon around the world. More and more inclusive children's literature is written to "represent the diversity in society" (Prater, 2003: 47) to promote empathy and uphold dignity. This part presents some recommendations of accessible inclusive children books around the world illustrating characters with physical and non-physical impairments which can be used to promote empathy and to dignify children.

\section{Inclusive Children's Literature Illustrating Physical Impairments Visual Impairment}

Quite a number of inclusive children's literature are written to illustrate people with visual impairment. One of the earliest inclusive children's book which is published is The seeing stick by Jane Yolen and Daniela Terrazzini in 1977. The book tells the story of a blind Chinese princess who never saw the world through her eyes. No magicians nor physicians could cure her until one day a wise, blind, old man taught her to see with the tip of her fingers. The seeing stick tells the readers that there is more than one way to see the world. Another example is The sound of colors by Jimmy Liao, published in 2006. The story revolves around a girl who lost her sight some time ago. This young, blind girl traveled from one subway station to another, imagining she was going from one wonder to another. Her mind took her to all wonderful places she could imagine. Both The seeing stick and The sound of colors presents beautiful illustrations full of colors. Readers are taken to experience the colors from the characters' perceptions. However, another story titled The black book of colors (Cottin, Faria, and Amado, 2008) did more than just relying on the storyline. This book promotes empathy for the visually impaired by strengthening readers' sensitivity of identifying colors beyond visions. A very simple story in which a narrator, Thomas, described how he perceived colors as a blind kid. He narrated the taste of red, the feeling of black, the sound of yellow, and the smell of green. The striking features about this book is that the story is printed in black and white. The words are printed in white on black and the illustrations are printed in black on black. This book also uses braille in the narration, allowing readers to learn braille and to have a little experience empathizing with the blinds. The illustrations use raised lines, black on black. Readers are able to use their sense of touch when going through the illustrations.

\section{Hearing Impairment}

The Moses series are good examples of inclusive children's books related to deafness. Millman's (1998) Moses goes to a concert tells about a young deaf student who met a deaf percussionist in an orchestra concert during his school's field trip. The character learnt how to feel the vibrations of the music, and had the opportunity to play different percussion instruments. In Moses goes to school (Millman, 2000), the story revolves around Moses' school activities with other deaf students from diverse ethnics. The interaction was illustrated naturally in different social settings. Both books illustrate American Sign Language (ASL) and ASL hand alphabet, allowing the readers to learn ASL. Another accessible book is Leila ruddi allaya (Kaadan, 2011). The book was awarded the "Best Fiction Book for Children with Special Needs" in 2011 from the Anna Lindh foundation. It tells about a girl living in a high orange tower, similar to Rapunzel, waiting for her prince to come. The character of Leila was portrayed as an empowered protagonist who spoke her own language. It was the prince, Sami, who had to struggle to communicate to her and finally had the realization that they spoke different language. Along with the realization came understanding and communication. The characters of these books are portrayed as empowered individuals who have their place in the world. These books teach readers that there are many ways to communicate, even 
when we have different ways of communication.

\section{Other Physical Impairments.}

Noi (Mazzoli and Possentini, 2014) is a beautiful Italian story of Phillip, a boy with face disfigurement, a deformed eye. This is one of the rarest topics in children's literature. Phillip was the object of bullying by his peers. He was an outsider and spent most of his time in fear of the bullying, until he befriended with other outsiders and they found a safe place in each other's. This book sums up human tendencies to judge others based on looks as we often draw false conclusions. Another inclusive children's book draws the topic of paraplegia. Lola la loba, Lola the wolf, (Taboada and Wensell, 2011) tells the story of a wolf who lost her ability to walk after an accident. The story teaches readers how to be independent without being too proud. The character was having a journey of learning how to make choices on her own, but humble enough to accept help when needed.

There are more titles of inclusive children's literature which illustrates physical impairments. However, due to the inaccessibility to the full story which leads to the lack of information, this paper will not elaborate them in the recommendation.

\section{Inclusive Children's Literature Illustrating Non-physical (Social and Mental) Impairments}

There are many aspects of social and mental impairments, from autism to attention deficiency, from down syndrome to selective mutation. The variety of topics in this category is diverse, thus the examples of the literature for this part are not subcategorized. Some accessible books promoting the topics of non-physical impairments are as follow.

\section{El Cazo de Lorenzo (Lorenzo's Saucepan).}

The story of Lorenzo and his saucepan was written by Isabelle Carrier and published in 2010. The unique story with metaphorical message is very amusing for readers. Even though the disability was not clearly defined in the story, but it was clear that Lorenzo was not like everybody else. The story started when Lorenzo got hit by a saucepan in the head. He has never been the same ever since. He had to drag the saucepan around with him whenever he went. The saucepan often became the reason for the difficult situations he found himself in. All his good quality was overlooked by people because they focused on the saucepan that Lorenzo dragged around. Eventually, he was able to make peace with himself and managed to use the saucepan for his benefit.

This quirky story is brilliantly written by unspecifying the impairment that the character possesses. This extend the relevance of the character to many children, with or without impairments. Therefore, different readers can get different experience after reading the book.

\section{Hi! I'm Ben! ... and I've got a secret (Bouwkamp and Tesnar, 1995)}

Bouwkamp illustrates a character with Down syndrome in this story. The story started by the introduction of a 3-year-old boy named Ben, who asked readers to guess his secret. The description that Ben gave about himself was similar to other kids. He liked what other kids liked and did what other kids did. Yet, he described himself as "special" for, unlike other kids, he needed extra help in doing things and he found it difficult to talk fluently.

This story describes Down syndrome by representing it positively. The character has a loving family who supports him. This book is great in helping children relate to someone who is different from themselves. The illustrations of common experience promote understanding that even though people are different, they actually have a lot in common, thus it is quite possible that they can be friends.

\section{Leo the Late Bloomer (Kraus and Aruego, 1971).}

This book is about Leo, a little tiger, who did not progress as fast as others in his age. Leo was not able to do things as others. He 
was not able to speak, read, write, or draw, and it made him very sad. His family was also sad because he was not as they expected. It took a very long time until Leo was finally able to speak, read, write, and draw. It took a lot of efforts from him and from his family. In the end, he was able to what others could. This book teaches readers that it is alright not to have a different pace of learning. It shows that people will be capable in their own time.

\section{Conclusion}

Inclusive children's literature is significant to uphold children's dignity in a way that this literature enables them to learn about their place in the world. Promoting inclusive children's literature is highly important regarding the positive effects it brings on all children's character. Indirect contact with disability through children's literature can be highly influential in developing children's positive attitudes towards people with disabilities and towards themselves. If intervention as simple as reading inclusive literature to children can bring a lot of benefits and be so influential, it would be highly beneficial to put inclusive children's literature in Indonesian collections of children's literature.

\section{References}

Adioetomo, S. M., D. Mont, and Irwanto. "Person with Disabilities in Indonesia: Empirical Facts and Implications for Social Protection Policies (Official Report of Tim Nasional Percepatan Penanggulangan Kemiskinan)", 2014. $<$ tnp2k.go.id/images/uploads/download s/Disabilities\%20report\%20Final\%20se pt2014\%20.pdf>

Ayala, E. C. "Poor Little Things and Brave Little Souls: The Portrayal of Individuals with Disabilities in Children's Literature", Reading Research and Instruction, 39 (1), 103-117, 1999.
Beckett, A. and S. Barret. "Inclusion Literature: A Guide to Books for Disability Awareness (Booklet of DEEPS Project)", 2008. <sociology.leeds.ac.uk/ assets/files/research/deeps/inclusionlit eratureguide .pdf>

Bouwkamp, J. and D. Tesnar. Hi, I'm Ben! And I've Got a Secret. Rochester Hills: Band of Angels Press, 1995.

Carrier, I. El Cazo de Lorenzo. Barcelona: Editorial Juventud, 2010.

Cottin, M., R. Faria, and E. Amado. The Black Book of Colors. Toronto: Groundwood Books, 2008.

Freud, S. Civilization and Its Discontents. New York: Doubleday Anchor Books, 1958.

Govindarajan, M., S. Natarajan, and V. S. Senthilkumar. Professional Ethics and Human Values. Delhi: Prentice-Hall of India Pvt. Ltd, 2013.

Kaadan, N. Leila Ruddi Allaya. Damascus: Box of Tales Publishing House, 2011.

Kraus, R. and J. Aruego. Leo the Late Bloomer. New York: Simon \& Schuster Books for Young Readers, 1971.

Krismariana, C and Thomdean. Kita Bisa Bersahabat, Rin!. Yogyakarta: Sahabat Gloria, 2007.

Kustawan, D and B. Hermawan. Model Implementasi Pendidikan Inklusif Ramah Anak. Jakarta: Luxima, 2013.

Liao, J. The Sound of Colors. New York: Little, Brown Books for Young Readers, 2006.

Lindsay, G. "Inclusive Education: A Critical Perspective". British Journal of Special Education, 30 (1), 3-12, 2003.

Mazzoli, E. and S. M. Possentini. Noi. Bologna: Corso Bacchilega Editore, 2014. 
McDonald, N. and D. Messinger. "The Development of Empathy: How, When and Why". Free Will, Emotions, and Moral Actions: Philosophy and Neuroscience in Dialogue, 2011.

Millman, I. Moses Goes to a Concert. New York: Frances Foster Books, 1998.

Millman, I. Moses Goes to School. New York: Frances Foster Books, 2000.

Piaget, J. The Moral Judgement of the Child. New York: Harcourt, 1965.

Pramudyawati, N. and N. P. Ar-Rizqi. Seri Explorasi dan Bermain untuk: Anak Berkebutuhan Khusus. Yogyakarta: Penerbit Pohon Cahaya, 2014.

Prater, M. A. "Learning disabilities in children and adolescents literature: how are characters portrayed?". Learning Disability Quarterly, 26 (1), 47-62, 2003.

Taboada, A. and U. Wensell. Lola la Loba. Puerto Rico: Ediciones SM, 2011.

Vygotsky, L . The Collected Works of L. S. Vygotsky Vol. 2: The Fundamentals of Defectology (Abnormal Psychology and Learning Disabilities. R. W. Rieber and A. S. Carton (eds.). New York: Plenum Press, 1993.

Wellman, H. M., D. Cross, and J. Watson. "Meta-analysis of Theory-of-mind Development: The Truth about False Belief". Child Development, 72, 655-684, 2001.

Wiyani, N. A. Buku Ajar Penangangan Anak Usia Dini Berkebutuhan Khusus. Yogyakarta: Ar-Ruzz Media, 2014.

World Health Organization and The World Bank. World Report on Disability, 2011. $<$ unicef.org/protection/World_report_on _disability_eng.pdf>

Yolen, J. and D. J. Terrazzini. The Seeing Stick (Reprint Ed). Philadelphia: Running Press Kids, 2009.
Yuditia, R., Y. D. Liandarwati, and P. Palupi. Mari Memahami dan Melindungi Anak Melalui Inklusi Sosial. Surabaya: Samitra Abhaya KPPD, 2015.

Zahn-Waxler, C., M. Radke-Yarrow, E. Wagner, and M. Chapman. "Development of Concerns for Others". Developmental Psychology, 28, 126-136, 1992. 